\title{
Enlarged brick blocks as an alternative to masonry
}

\author{
Maria Prusakova ${ }^{1}$, Armen Mkrtchyan ${ }^{1}$, and Evgeniy Pugach $^{1 *}$ \\ ${ }^{1}$ Moscow State University of Civil Engineering, Yaroslavskoe shosse, 26, 129337, Moscow, Russia
}

\begin{abstract}
Brick structures are one of the most common and useful construction materials. However, brick laying consists of the most laborintensive processes with the largest part of manual works. The main purpose of the research is to find an alternative technology for the brick structures construction that have geometric and physical parameters of brickwork, the processes of which are less labor-intensive and more mechanized. Using factory-made enlarged brick blocks was suggested in the article as an alternative. A brick block is a factory - made element of a brick wall structure that is installed in the design position by crane equipment. By reducing the part of manual labor in installing the brick block, the total duration of construction is reduced while maintaining the final result $-\mathrm{a}$ brick wall. The research method was a comparative analysis of the resulting indicators of construction of structures made of individual bricks and installation of enlarged brick blocks. As a model for comparative analysis, a brick wall of specified parameters was proposed, on the basis of which calculations were made. The results show diagrams of labor and material resources spent on the construction of the wall for the two technologies under consideration. Based on the results obtained, we can conclude that it is possible to use enlarged brick blocks of high factory readiness as an alternative to masonry.
\end{abstract}

\section{Introduction}

Modern house-building involves a large number of stone works, namely - brickwork. Brickwork is used both as a frame filling in monolithic housing construction, and as supporting structures of low-rise buildings made of brick [1]. Due to its good load-bearing capacity, the possibility of use in layered insulating lightweight structures, masonry is actively used for the construction of load-bearing and enclosing walls. However, it has a significant drawback - the high complexity of work and the dominance of manual labour. The modern construction industry seeks to increase the rate of production of finished products, which requires a decrease in the number of operations and an increase in the degree of mechanization of technological processes [2]. As you know, the entire process of masonry, except for the supply of mortar and brick to the place of work, is carried out manually. Manual labour requires various skills of performers and, in contrast to mechanized processes, more careful control. One solution to this problem may be the preliminary assembly and use of

\footnotetext{
*Corresponding author: tsp-tvz@mail.ru
} 
enlarged brick blocks [14]. Pre-fabricated enlarged brick blocks will reduce the amount of manual labour and increase the degree of mechanization, increase productivity and quality of work. The prospects of using this technology in modern construction will be disclosed in this article.

\section{Methods}

A study was conducted to consider the possibility of applying and justifying the alleged effectiveness of using structures of brick blocks in modern construction. As a theoretical justification of the effectiveness of this technology compared with conventional masonry, a comparative analysis of the resulting indicators of the construction of brick structures of a single volume is performed. In the framework of the study, a model of a wall section with a length of $10 \mathrm{~m}$, a height of $3.525 \mathrm{~m}$ and a thickness of 250,380 and $510 \mathrm{~mm}$ was considered. The height of the enlarged block is $875 \mathrm{~mm}$, the length is $1030 \mathrm{~mm}$, which may correspond to the location mark and the dimensions of the openings.

To determine the effectiveness of the methods under consideration for each construction option, the composition of technological operations and labor costs are determined.

The main working operations in the production of stone work are the supply and layout of bricks, spreading the mortar, laying bricks in the case, scaffolding [1]. It is possible to optimally organize work by breaking down the building according to a gripping-tier system, which determines the leading process - masonry [1]. The size and number of grips should be consistent with the performance of the masons.

The main process when using enlarged brick blocks is installation. When conducting installation work, the blocks must be installed around the entire perimeter of the building being constructed without gaps. If this is not possible, lag is allowed no more than 1 tier. The gap should be located in the openings. Previously, the position of the blocks is marked according to the layout scheme [3].

Similar to how the laying of joints must be observed when laying bricks [4], enlarged brick blocks are installed according to the system of the corresponding wall of the same width [15]. Laying of blocks is done with dressing of joints in the following order: on solid sections of walls, the blocks of the upper row should overlap the blocks of the lower row by at least $1 / 4$ the length of the block, and for blocks shorter than one meter at least $25 \mathrm{~cm}$. Additional connection between the blocks is also provided by laying between the joints reinforcing nets and T-shaped embedded parts made of strip steel [4].

The pattern for bricklaying is setting the rules and pulling the moorings [5]. These auxiliary processes ensure the quality of work: this not only simplifies the construction process itself, but also guarantees the construction of a wall that is even throughout [13].

The same requirements apply to structures made of blocks. Their manufacture is possible in the following ways: face tier, formwork and using templates [6].

When using the face tier method, the blocks are made directly at the erected building or at the factory sites using tools, equipment and devices used for ordinary piece bricklaying [9]. Here, as well as during the construction of walls made of separate bricks, the process is divided into separate operations entrusted to masons of various qualifications, but due to the unification of products, the stationarity of workplaces, the absence of the need for supply and placement of materials on the scaffolds, their labour productivity is much higher.

In the formwork method, the masonry is carried out in the same way as with the milestone, but with the use of special formwork, which limits one of the sides of the block [7].The surface of the panels in order to avoid adhesion of the solution is sheathed with tin or plastic sheets. Thanks to the formwork, workers of less skill can lead the masonry. To enlarge the 
blocks, they use the same techniques, tools and devices as for laying structures in the design position [7].

With the mechanized method, there is no need to use the usual tools, preference is given to special conductors, and the absence of certain processes and operations increases the productivity of the masons [8]. In addition to lowering the cost of resources, the quality of the blocks is getting better: the geometry of the shapes, the required dimensional accuracy, and the horizontal rows in the masonry are ensured.

Organization of masons. Since the wall height is $3.525 \mathrm{~m}$, work in both cases is carried out from the scaffold. When masonry is made in one brick $(250 \mathrm{~mm})$, the work is carried out by a "two" link using articulated-block scaffolds on the outside of the wall to access the structure during jointing [5]. It is advisable to erect a wall with a thickness of $380 \mathrm{~mm}$ by a "three" link with the arrangement of scaffolds on the outside of the wall. For masonry walls in two bricks $(510 \mathrm{~mm})$, the link "five" means of conditioning are placed on both sides of the structure being constructed. The brick is supplied in the reserve necessary for 2-4 hours of operation of the unit, the solution - 1 hour, then - as the materials are consumed [10].

Installation of enlarged blocks begins with the installation of external lighthouse blocks, which are located at the corners of the building [12]. A mooring cord is pulled along them, with the help of which the remaining intermediate blocks are mounted. The enlarged elements are put one after another without gaps [11]. After installing one row of blocks along the contour of the walls, check the horizontal position of the installation, install parts that provide a connection of the corners. Places of laying ties and their parameters are directly provided by the project. Before laying, the welded wire mesh is covered with cement milk and embedded in a mortar bed [13]. The correct position of the unit during its installation is checked by plumb and level. With a slight alignment of the elements using scrap. If it is necessary to change the position of the block completely, it should be lifted, taken to the side, replaced with a solution in bed, reinstalled [6].

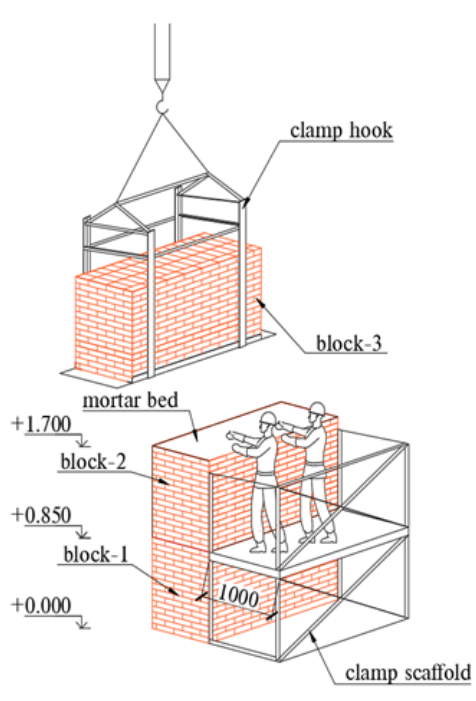

Brick masonry workplace organization
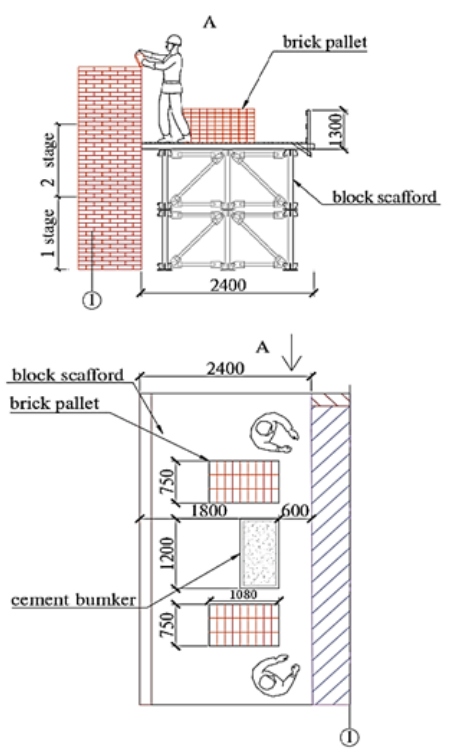

Workplace organization during installing a brick block

Fig.1. Organization of a workplace. 


\section{Results}

To conduct a comparative analysis of technologies, on the basis of regulatory documents, a calculation of labor costs for brick blocks construction was compiled, the results of which are presented in the form of a diagram in table 1.

Table 1. Labor costs in man hours for one brick block construction.

\begin{tabular}{|c|c|c|c|c|c|c|c|c|c|}
\hline \multirow[t]{2}{*}{ № } & \multirow[t]{2}{*}{ Technological proceses } & \multirow{2}{*}{ 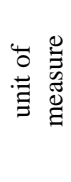 } & \multirow{2}{*}{ 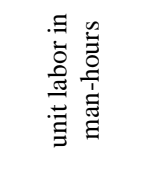 } & \multicolumn{3}{|c|}{$\begin{array}{c}\text { scope of works/ } \\
\text { width of wall in mm. }\end{array}$} & \multicolumn{3}{|c|}{$\begin{array}{c}\text { Labor costs in man } \\
\text { hour }\end{array}$} \\
\hline & & & & 250 & 380 & 510 & 250 & 380 & 510 \\
\hline 1 & $\begin{array}{l}\text { Premixing of cement grout } \\
\text { in grout mixer }\end{array}$ & $\mathrm{m}^{3}$ & 0.6 & $\begin{array}{c}1.9 \\
4\end{array}$ & $\begin{array}{c}2.9 \\
4\end{array}$ & 3.95 & 1.16 & 1.76 & 2.37 \\
\hline 2 & Bricklaying of brick block & $\mathrm{m}^{3}$ & $3.2 / 2.6 / 2.3$ & $\begin{array}{c}8.7 \\
5\end{array}$ & $\begin{array}{c}13 . \\
3\end{array}$ & 17.85 & 28.00 & $\begin{array}{c}34.5 \\
8\end{array}$ & $\begin{array}{c}41.0 \\
6\end{array}$ \\
\hline 3 & $\begin{array}{l}\text { Reinforcing mesh of brick } \\
\text { block }\end{array}$ & $\mathrm{Tn}$ & 63.73 & 0.1 & $\begin{array}{c}0.1 \\
5\end{array}$ & 0.2 & 0.096 & $\begin{array}{c}0.14 \\
4\end{array}$ & $\begin{array}{c}0.19 \\
2\end{array}$ \\
\hline 4 & Flushing of brick wall & $\mathrm{m}^{2}$ & 0.25 & 35 & 35 & 35 & 8.75 & 8.75 & 8.75 \\
\hline & & & & & & & 71.52 & 78.7 & $\begin{array}{r}85.7 \\
8 \\
\end{array}$ \\
\hline
\end{tabular}

Table 2 shows the General calculation of labor costs for the construction of the previously described model of a brick wall in two ways. In table 2 number I means labor costs for classic brick laying wall and number II for brick block technology.

Table 2. Comparison of labor costs for the construction of a brick wall with two technologies.

\begin{tabular}{|c|c|c|c|c|c|c|c|c|c|c|c|c|c|}
\hline \multirow{3}{*}{ 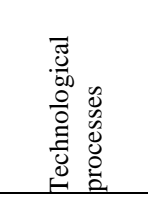 } & \multirow{3}{*}{ 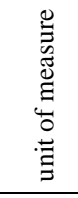 } & \multicolumn{4}{|c|}{$\begin{array}{c}\text { Wall } \\
250 \mathrm{MM}\end{array}$} & \multicolumn{4}{|c|}{$\begin{array}{c}\text { Wall } \\
380 \mathrm{Mm} \\
\end{array}$} & \multicolumn{4}{|c|}{$\begin{array}{c}\text { Wall } \\
510 \mathrm{Mm} \\
\end{array}$} \\
\hline & & \multicolumn{2}{|c|}{$\begin{array}{c}\text { scope of } \\
\text { works }\end{array}$} & \multicolumn{2}{|c|}{ man/hour } & \multicolumn{2}{|c|}{$\begin{array}{c}\text { scope of } \\
\text { works }\end{array}$} & \multicolumn{2}{|c|}{ man/hour } & \multicolumn{2}{|c|}{$\begin{array}{c}\text { scope of } \\
\text { works }\end{array}$} & \multicolumn{2}{|c|}{ man/hour } \\
\hline & & I & II & I & II & I & II & I & II & I & II & I & II \\
\hline $\begin{array}{l}\text { Brik } \\
\text { conveyance } \\
\text { in wooden } \\
\text { pallet }\end{array}$ & $\begin{array}{r}1000 \\
\text { items. }\end{array}$ & 4.49 & - & 0.95 & - & 6.8 & - & 1.43 & - & 9.15 & - & 1.93 & - \\
\hline $\begin{array}{l}\text { Cement } \\
\text { grout } \\
\text { conveyance }\end{array}$ & $\mathrm{M}^{3}$ & 1.94 & 0.2 & 0.3 & 0.03 & 2.94 & 0.3 & 0.45 & 0.05 & 3.95 & 0.4 & 0.6 & 0.06 \\
\hline $\begin{array}{l}\text { Premixing } \\
\text { of cement } \\
\text { grout in } \\
\text { grout mixer }\end{array}$ & $\mathrm{M}^{3}$ & 1.94 & 0.2 & 4.08 & 0.42 & 2.94 & 0.3 & 6.18 & 0.63 & 3.95 & 0.4 & 8.3 & 0.84 \\
\hline $\begin{array}{l}\text { reusable } \\
\text { scaffolds } \\
\text { installation }\end{array}$ & $10 \mathrm{M}^{3}$ & 0.87 & 0.87 & 1.26 & 1.26 & 1.33 & 1.33 & 1.92 & 1.92 & 1.79 & 1.79 & 2.57 & 2.57 \\
\hline $\begin{array}{l}\text { bricklaying } \\
\text { of wall } \\
\text { construction }\end{array}$ & $\mathrm{M}^{3}$ & 8.75 & - & 28 & - & 13.3 & - & 34.6 & - & 17.85 & - & 41.1 & - \\
\hline
\end{tabular}




\begin{tabular}{|c|c|c|c|c|c|c|c|c|c|c|c|c|c|}
\hline \multirow{3}{*}{ 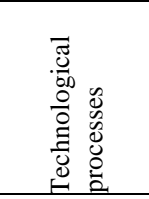 } & \multirow{3}{*}{ 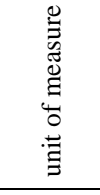 } & \multicolumn{4}{|c|}{$\begin{array}{c}\text { Wall } \\
250 \mathrm{Mm}\end{array}$} & \multicolumn{4}{|c|}{$\begin{array}{c}\text { Wall } \\
380 \mathrm{Mm}\end{array}$} & \multicolumn{4}{|c|}{$\begin{array}{c}\text { Wall } \\
510 \mathrm{MM}\end{array}$} \\
\hline & & \multicolumn{2}{|c|}{$\begin{array}{c}\text { scope of } \\
\text { works }\end{array}$} & \multicolumn{2}{|c|}{$\mathrm{man} /$ hour } & \multicolumn{2}{|c|}{$\begin{array}{l}\text { scope of } \\
\text { works }\end{array}$} & \multicolumn{2}{|c|}{ man/hour } & \multicolumn{2}{|c|}{$\begin{array}{c}\begin{array}{c}\text { scope of } \\
\text { works }\end{array} \\
\end{array}$} & \multicolumn{2}{|c|}{ man/hour } \\
\hline & & $\mathrm{I}$ & II & I & II & I & II & I & II & I & II & $\mathrm{I}$ & II \\
\hline $\begin{array}{l}\text { Reinforcing } \\
\text { mesh of } \\
\text { brick wall }\end{array}$ & Tn. & 0.1 & - & 6.373 & - & 0.15 & - & 9.56 & - & 0.2 & - & 12.7 & - \\
\hline $\begin{array}{l}\text { installation } \\
\text { of brick } \\
\text { blocks }\end{array}$ & 1 block & - & 40 & - & 13.2 & - & 40 & - & 18 & - & 40 & - & 18 \\
\hline $\begin{array}{l}\text { Flushing of } \\
\text { brick wal }\end{array}$ & M2 & 35 & - & 8.75 & - & 35 & - & 8.75 & - & 35 & - & 8.75 & - \\
\hline $\begin{array}{l}\text { Reinforcing } \\
\text { of brick } \\
\text { blocks }\end{array}$ & $\mathrm{T}$ & - & 0.07 & - & 2.85 & - & 0.1 & - & $\begin{array}{l}3 . \\
78\end{array}$ & - & 0.12 & - & 4.74 \\
\hline $\begin{array}{l}\text { block joints } \\
\text { concreting }\end{array}$ & $10 \mathrm{M}$ & - & 4 & - & 11.2 & - & 4 & - & $\begin{array}{l}11 \\
.2\end{array}$ & - & 4 & - & 11.2 \\
\hline & & & & 49.71 & $\begin{array}{c}28.9 \\
6 \\
\end{array}$ & & & 62.9 & $\begin{array}{r}35 \\
.6\end{array}$ & & & 76 & 37.41 \\
\hline
\end{tabular}

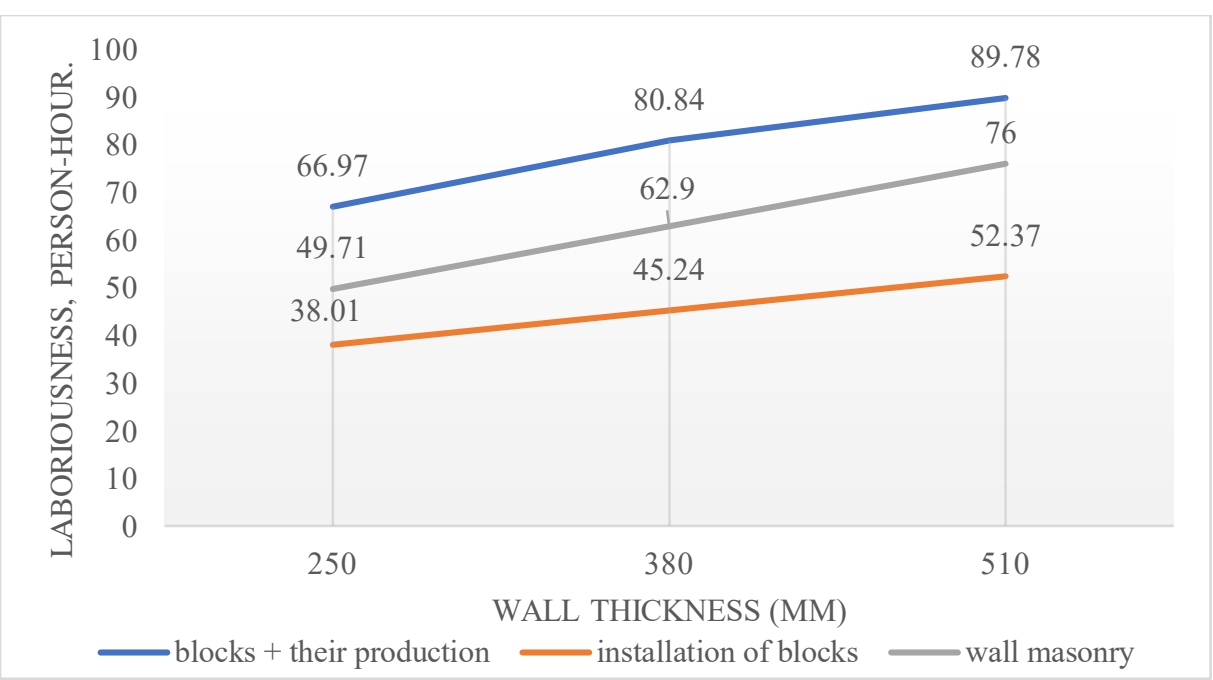

Fig.2. The complexity of the device wall structures from enlarged blocks and individual bricks.

According to the diagram, it is possible to trace that the total indicators of labor costs for manufacturing in the factory and the installation of brick blocks are on average $21 \%$ higher than the total labor costs for the construction of the considered wall of similar thickness from individual bricks. However, due to the possibility of early production or combination of manufacturing and installation processes, the erection of a structure of brick blocks can be $27.5 \%$ more effective relative to the construction of structures of individual bricks. 


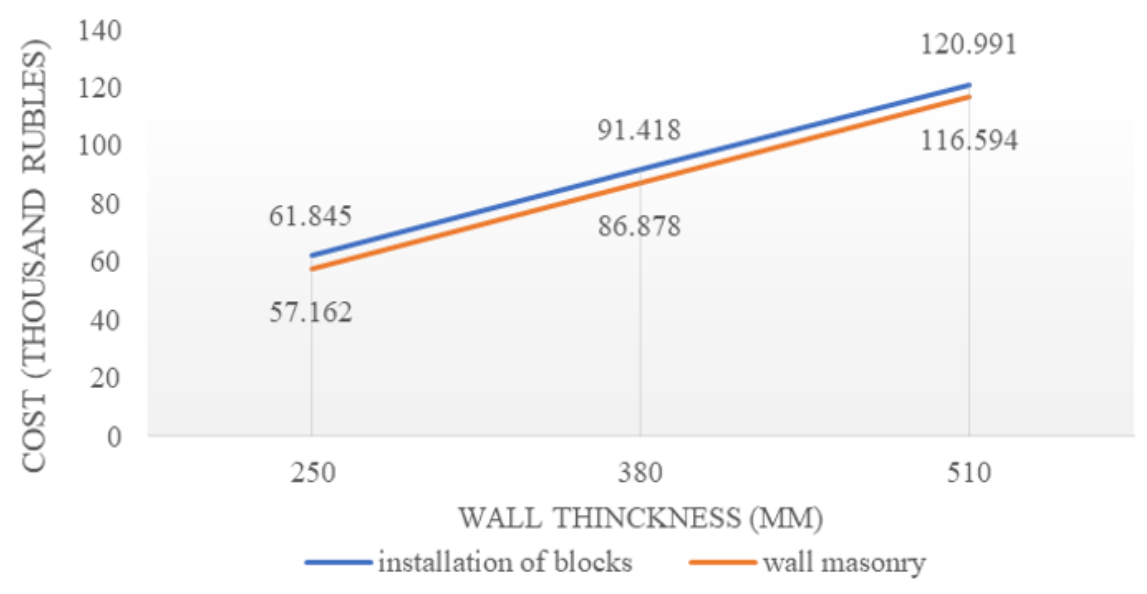

Fig.3. The cost of building wall structures from enlarged blocks and individual bricks.

From a comparison of the cost of construction of the considered design options, it follows that masonry is cheaper on average by $5 \%$ installation of enlarged elements. However, with significant differences in labor costs directly at the place of work (see Fig. 2), the technology of erecting a brick wall from blocks can be more efficient, which, moreover, meets modern requirements for the complex mechanization of construction production [7].

\section{Discussion}

Based on the results obtained theoretically, we can talk about the possibility of using enlarged elements of high factory readiness as an alternative to brickwork. However, modern buildings require a developed system of wall structures that combine high thermal insulation properties and the ability to decorate facades. These requirements set a new task - the improvement of brick blocks to an integrated facade element. To achieve this goal, it is necessary not only to modernize the design of the element itself, but also to consider in more detail the issue of dressing the blocks together, think over the butt sections of the walls, and also identify the minimum necessary requirements for installation technology and auxiliary equipment.

The possibility of manufacturing such a structure, delivery and installation means will significantly reduce the time of building construction, improve product quality and reduce the duration of work at height.

\section{Conclusion}

The use of brick blocks can reduce the number of masonry work on the construction horizon to a minimum, since $90 \%$ of their production is located either at the enlargement assembly point at the construction site, or at the manufacturer.

Brick blocks are delivered ready-made to the mounting horizon; all that is needed is to make the alignment and installation of the blocks in a row (according to the layout) to the design position.

Production of the structure in the factory also allows you to use greater opportunities for the delivery of materials of the first stage. The main advantage of the enlarged assembly of brick walls is the possibility of combining both production and logistics flows, which leads to a reduction in construction time.

Given the advantages of using enlarged elements and modern requirements for the industrialization of the building process, further development and improvement of the 
technology presented in the article allows us to talk not only about reducing the time for erecting directly stone structures, but also about reducing the cost of facade work.

\section{References}

1. E. Pugach, P. Gaidukov, P. Medvedev, IOP Conference Series Materials Science and Engineering 471, (2019). DOI: 10.1088/1757-899X/471/2/022035 P 23.

2. E. Bejder, S. Wandahl, New Cooperation Trends in the Building Industry, 10th International Colloquium - Planning instruments in project management, (2005).

3. Ž. Radovanović, Building materials and structures 58, 53-55, (2015). DOI:10.5937/grmk1502021r P

4. S. A. R. Shah, H. Arshad, Sustainable Brick Masonry Bond Design and Analysis: An Application of a Decision-Making Technique, Applied Sciences 9(20), (2019). DOI: 10.1088/1757-899X/471/2/022035 P 194-197.

5. E. Clois, Kicklighter, Job Practice Manual for Modern Masonry: Brick, Block, Stone, Published January, (2003).

6. N.A. Cherkasov, Stone and cladding, Published Gosstroyizdat of the Ukrainian SSR, (1961).

7. Z. Wang, J. Zhao, T. Liu, Bond-slip model for horizontal reinforcing bars in reinforced brick masonry, Engineering Structures 20115, (2019). DOI:10.1016/j.engstruct.2019.109770

8. Fast brick-based homogenized limit analysis for in- and out-of-plane loaded periodic masonry panels, Computers , Structures 23115, (2020). DOI:10.1016/j.compstruc.2005.09.005 P 395

9. M.V.S. Cavalcanti, A.M.X. Francisco, D.M. Rodrigues, D.G. Silva, Optimization of structural brickwork laying joints in concrete blocks, IBRACON Structures and Materials Journal 11(7), 115-134, (2018). DOI: 10.1590/s1983-41952018000100010

10. B.Whitehead, Productivity in bricklaying, 8(1), 1-10, (1973). DOI 0007-3628(73)900406.

11. R.A. Oliveira, F.A. Nogueira, Silva C.W.A. Pires Sobrinho, A.C. Azevedo, Construction and Building Materials 182, (2018). doi.org/10.1016/j.conbuildmat.2018.06.092, P. 2034

12. B.Whitehead, Productivity in bricklaying, Building Science 8(1), (1973) doi.org/10.1016/0007-3628(73)90040-6, P. 1-10

13. A. Daniela, Geisler, A. Sampathkumar, M. Mutwil, S. Persson, Current Opinion in Plant Biology 11(6), (2008) DOI:10.1016/j.pbi.2008.08.003 P. 647-652

14. A.W. Emeritus, Hendry, Construction and Building Materials, 15(8), (2001) DOI: 10.1016/S0950-0618(01)00019-8 P. 323-330

15. B. Peng, D. D. Wang, G. Zong, Y. Zhang, Construction and Building Materials, 163(28), (2018). DOI: 10.1016/j.conbuildmat.2017.12.133 P. 656-667 